\title{
EFEKTIVITAS MODEL PEMBELAJARAN INKUIRI TERBIMBING DALAM MENINGKATKAN PEMAHAMAN KONSEP IPA SISWA SMP
}

\author{
N. K. Dewi Septiari, I. Nyoman Suardana, Kompyang Selamet
}

\author{
Program Studi S1 Pendidikan IPA \\ Universitas Pendidikan Ganesha \\ Singaraja, Indonesia
}

E-mail : \{dewi.septiari,nyoman.suardana,kompyang.selamet\}@undiksha.ac.id

\begin{abstract}
Abstrak
Penelitian ini bertujuan menganalisis efektivitas model pembelajaran inkuiri terbimbing dalam meningkatkan pemahaman konsep IPA siswa. Penelitian eksperimen semu ini menggunakan rancangan nonequivalent pretest-posttest control group design. Populasi penelitian adalah seluruh siswa kelas VIII SMP Negeri 3 Sukasada tahun ajaran 2017/2018 yang berjumlah 106 orang yang tersebar ke dalam empat kelas. Sampel penelitian ini adalah siswa kelas VIII A dan VIII B yang dipilih dengan teknik cluster random sampling. Siswa kelas VIII A dibelajarkan dengan model pembelajaran inkuiri terbimbing sedangkan kelas VIII B dibelajarkan dengan model pembelajaran langsung. Data tes pemahaman konsep dikumpulkan dan dianalisis dengan menggunakan uji ANCOVA satu jalur dengan taraf signifikansi 0,05. Hasil penelitian menunjukkan bahwa pemahaman konsep IPA siswa yang dibelajarkan dengan model pembelajaran inkuiri terbimbing lebih tinggi dibandingkan siswa yang dibelajarkan dengan model pembelajaran langsung dengan skor rata-rata posttest secara berturut-turut sebesar 76,4 dan 58,3 .
\end{abstract}

Kata kunci : pemahaman konsep, inkuiri terbimbing, pembelajaran langsung

\begin{abstract}
This study aims to analyze the effectiveness of guided inquiry learning model in improving students' understanding of science concept. This quasi-experimental study used nonequivalent pretest-posttest control group design. The study population is all students of class VIII SMP Negeri 3 Sukasada 2017/2018 academic year which amounted to 106 people divided into four classes. The sample of this research is students of class VIII $A$ and VIII $B$ selected by cluster random sampling technique. Grade VIII A students are taught by guided inquiry learning model while class VIII $B$ is taught by direct learning model. The understanding concept test data was collected and analyzed using a one-way ANCOVA test with level of significance 0.05 . The results showed that understanding the concept of science students who were taught by inquiry learning model was better than the students who were taught by direct learning model with the average score of posttest in a row of 76.4 and 58.3 .
\end{abstract}

Keywords: understanding concepts, guided inquiry, direct learning

\section{PENDAHULUAN}

Pendidikan merupakan salah satu aspek yang sangat berpengaruh terhadap kemajuan bangsa untuk meningkatkan mutu sumber daya manusia (SDM) (Wardani, 2015). Pendidikan yang berkualitas akan menghasilkan SDM yang cerdas, berkualitas dan mampu bersaing di era global ini yang akan berdampak pada kemajuan bangsa dan negara.
Tujuan pendidikan nasional yang tercantum pada Pasal 3 Undang-Undang No. 20 Tahun 2003 tentang Sistem Pendidikan Nasional menyatakan bahwa pendidikan nasional berfungsi untuk mengembangkan potensi peserta didik agar menjadi manusia yang beriman, bertakwa kepada Tuhan Yang Maha Esa, berakhlak mulia, sehat, berilmu, cakap, kreatif, mandiri, dan menjadi warga negara yang demokratis serta bertanggung jawab. 
Untuk mencapai tujuan pendidikan yang diinginkan pemerintah Indonesia dengan giat menyusun dan mengembangkan program untuk meningkatkan mutu pendidikan salah satunya adalah dengan melakukan penyempurnaan kurikulum. Kurikulum saat ini yang dikembangkan oleh pemerintah adalah kurikulum 2013. Kurikulum 2013 diharapkan dapat meningkatkan kompetensi sikap pengetahuan dan keterampilan untuk bersaing di dunia internasional (Murfiah, 2017). Kurikulum 2013 adalah kurikulum berbasis kompetensi dan karakter secara terpadu yang merupakan penyempurnaan kurikulum 2006 (KTSP).

Salah satu mata pelajaran pokok yang penting dalam kurikulum 2013 yaitu Ilmu Pengetahuan Alam (IPA). IPA adalah ilmu yang mempelajari gejala-gejala alam yang dapat dirumuskan kebenarannya secara empiris (Widiawati, 2015). Pembelajaran IPA diharapkan dapat menjadi wahana bagi siswa untuk mempelajari diri sendiri dan alam sekitar, serta prospek pengembangan lebih lanjut dalam menerapkan dikehidupan seharihari (Widiawati, 2015). Penggunaan Kurikulum 2013 akan menuntut siswa untuk aktif dalam setiap proses pembelajaran IPA karena kurikulum 2013 menekankan pembelajaran yang bersifat student centreded sehingga guru hanya sebagai fasilitator dalam pembelajaran, sehingga siswa dituntut untuk terlibat secara aktif mengembangkan potensi yang dimilikinya. Pembelajaran IPA tidak sekedar menuntut siswa menghafal sejumlah konsep dan prinsip IPA yang ada. Pembelajaran IPA seharusnya diarahkan untuk mengembangkan kebiasaan siswa mengonstruksi pemahamannya agar lebih baik, pemahaman konsep yang dibangun melalui kegiatan aktif siswa sangat menentukan keberhasilan belajar siswa. benar dan tepat sehingga memberikan pengalaman yang bermakna bagi siswa. Pembelajaran IPA dengan menggunakan kurikulum 2013 jika dilaksanakan dengan baik akan memperoleh hasil yang sangat memuaskan terutama dalam pemahaman konsep siswa.
Berkaitan dengan tujuan pendidikan IPA yaitu untuk mengantarkan siswa memahami konsep-konsep IPA dan untuk dapat memecahkan masalah terkait dengan kehidupan sehari-hari, maka dalam proses pembelajaran IPA siswa diberikan untuk mengembangkan potensi dan kemampuan yang ada pada diri siswa agar pengetahuan yang dimiliki siswa terkonstruksi dengan benar. Pemahaman konsep siswa yang baik akan menyebabkan siswa memiliki ingatan jangka panjang sehingga siswa dapat mengkonstruksi pengetahuannya (Tariani, Syahrudin \& Parmiti, 2014).

Kenyataannya pemahaman

konsep di Indonesia masih jauh dari harapan yang diinginkan terutama dalam pembelajaran IPA yang diinginkan. Hal ini dibuktikan dengan hasil Trends in International Mathematics and Science Study (TIMSS). Hasil TIMSS tahun 2011 untuk bidang sains Indonesia menepati peringkat ke 36 dari 42 negara dengan skor rata-rata 406 di mana rata-rata skor TIMSS adalah 500. Kemudian tahun 2015 menempatkan Indonesia pada peringkat 46 dari 51 negara dengan skor 397 lebih rendah dari skor rata-rata yaitu 500 (Martin et al, 2015). Indonesia mendapatkan peringkat low science benchmark. Makna peringkat tersebut menyatakan siswa Indonesia hanya mampu mengenal sebagian fakta-fakta dasar dari ilmu sains, menafsirkan diagram bergambar sederhana dan hanya mampu menerapkan pengetahuan dasar yang dimilikinya. Data tersebut memperlihatkan bahwa prestasi siswa dalam pembelajaran IPA di Indonesia masih rendah. Rendahnya peringkat siswa dalam bidang IPA salah satunya satunya disebabkan oleh kecenderungan siswa menghafal materi pelajaran yang berdampak pada rendahnya pemahaman konsep siswa. Mardhiyanti dalam Aisyah (2013) mengatakan bahwa dalam penyelesaiannya soal-soal TIMSS menuntut siswa untuk berpikir tingkat tinggi sehingga untuk dapat menyelesaikan soal tersebut siswa harus mampu menginterpretasikan dan mengembangkan konsep yang dipelajarinya.

Fakta terbaru yaitu di Provinsi Bali dapat dilihat dari nilai rata-rata ujian 
Nasional tingkat SMP tahun 2016 dan tahun 2017 pada mata pelajaran IPA mengalami penurunan. Terjadi penurunan 7,66 poin yakni dari nilai rata-rata 58,11 yang artinya kemampuan siswa berada pada kualifikasi sedang turun menjadi 50,45 yang artinya kemampuan siswa berada pada kualifikasi kurang (Kemendikbud, 2017). Menurut Kementrian Pendidikan Indonesia penurunan hasil UN disebabkan karena meningkatknya tipe soal yang digunakan. Tipe soal yang digunakan yaitu High Order Thinking Skill sehingga menuntut siswa untuk bernalar tinggi karena soal yang digunakan sejenis dengan tipe soal TIMSS dan PISA. Hal tersebut menyebabkan siswa harus mampu menginterpretasikan dan mengembangkan konsep yang dipelajarinya untuk mendapatkan nilai yang maksimal karena pemahaman konsep yang baik merupakan dasar untuk dapat melangkah ketingkatan berpikir yang lebih tinggi. Hasil penelitian tersebut memperlihatkan hasil belajar siswa dan pemahaman konsep siswa di Indonesia masih rendah terutama dalam pembelajaran IPA.

Rendahnya pemahaman konsep dalam pembelajaran IPA disebabkan oleh faktor-faktor tertentu, yaitu faktor internal dan eksternal. Faktor internalnya, meliputi pola belajar yang bersifat hafalan, bertahan pada konsep-konsep yang salah dan faktor eksternal yang dimaksud seperti pengemasan pembelajaran, metode mengajar, interaksi guru dan siswa (Hariyadi, Ibrohim \& Rahayu, 2016).

Berdasarkan hasil observasi yang peneliti lakukan di SMP Negeri 3 Sukasada pada bulan Oktober 2017, guru masih menggunakan metode ceramah dalam pembelajaran, meskipun dalam perangkat pembelajaran yang dibuat guru menggunakan pembelajaran EEK akan tetapi dalam implementasi di kelas guru masih menggunakan model pembelajaran langsung (Direct Instruction). Pembelajaran langsung memilki lima tahapan kegiatan pembelajaran yaitu (1) menyampaikan tujuan dan mempersiapkan siswa (2) mendemonstrasikan pengetahuan dan keterampilan membimbing pelatihan (4) mengecek pemahaman dan memberikan umpan balik
(5) memberikan kesempatan untuk pelatihan lanjutan dan penerapan (Kardi \& Nur dalam Trianto, 2010). Penggunaan model pembelajaran langsung dalam proses pembelajaran cenderung membuat siswa menjadi pasif karena kegiatan pembelajaran tidak berpusat pada siswa melainkan berpusat pada guru sehingga motivasi siswa dalam mengikuti pembelajaran menjadi rendah. Pembelajaran langsung juga cenderung menyebabkan siswa menghafal materi pembelajaran sehingga pemahaman siswa terhadap materi pelajaran bersifat sementara. Hal tersebut menjadi salah satu faktor rendahnya pemahaman siswa terhadap suatu konsep pelajaran, padahal pemahaman konsep merupakan hal yang sangat berperan penting dalam pembelajaran. Pemahaman konsep merupakan kemampuan siswa dalam menguasai materi, sehingga siswa tidak hanya mengingat konsep, namun siswa harus mampu menginterpretasikan konsep yang dipelajarinya. Penggunaan model pembelajaran yang sesuai akan memudahkan siswa dalam menerima konsep yang diberikan oleh guru. Terdapat tujuh Indikator pemahaman konsep yang harus dicapai siswa menurut taksonomi Bloom,s yaitu (1) menafsirkan, (2) memberi contoh, (3)mengklasifikasikan, (4) membandingkan, (5) merangkum, (6) menyimpulkan dan (7)menjelaskan (Anderson \& Krathwol, 2015).

Djamarah, Bahri \& Zain (2013) menyatakan bahwa model pembelajaran langsung lebih banyak menekankan keaktifan guru daripada peserta didik sehingga menyebakan siswa menjadi pasif. Kurniawati (2014) juga menyatakan bahwa pembelajaran dengan model pembelajaran langsung yang sering diterapkan guru mengakibatkan siswa enggan dan jenuh dalam menerima materi pelajaran sehingga tujuan yang ditetapkan tidak tercapai secara optimal dan menyebabakan prestasi belajar siswa rendah.

Salah satu model pembelajaran yang dapat memudahkan siswa dalam menerima konsep yang diberikan oleh guru adalah model pembelajaran inkuiri terbimbing. Model pembelajaran inkuiri terbimbing bersifat student centered 
karena model ini memberikan lebih banyak kesempatan bagi siswa untuk mengembangkan self concept yang lebih baik. Model Pembelajaran inkuiri terbimbing memiliki enam tahapan dalam kegiatan pembelajaran yaitu merumuskan masalah (2) merumuskan hipotesis (3) merancang percobaan (4) melakukan percobaan (5) mengumpulkan dan menganalisis data (6) menyimpulkan (Eggen \& Kauchak dalam Trianto, 2010). Siswa diharapkan dapat menemukan sendiri jawaban dari suatu permasalahan yang ingin dipecahkan melalui model pembelajaran inkuri. Hal ini sesuai dengan teori belajar kontruktivisme yang dikembangkan oleh Piaget yaitu pengetahuan akan lebih bermakna jika dicari dan ditemukan sendiri oeh siswa (Dahar, 2011).

Model pembelajaran inkuiri terbimbing memiliki keunggulan dibandingkan dengan model pembelajaran langsung. Menurut Trianto (2010), keunggulan penggunaan model pembelajaran inkuiri terbimbing adalah memacu keinginan siswa untuk mengetahui, memotivasi mereka untuk melanjutkan pekerjaan sehingga mereka menemukan jawaban dan menyelesaikan masalah secara mandiri. Manfaat yang diperoleh bagi siswa dalam pembelajaran inkuiri adalah siswa akan memahami konsep-konsep dasar dan ide-ide lebih baik, membantu dalam menggunakan daya ingat dan transfer pada situasi-situasi proses belajar yang baru dan mampu mengembangkan pemahaman konsep siswa.

Kurniawati et al (2014) dan Widiawati (2015) menyatakan pemahaman konsep peserta didik yang di belajarkan dengan pembelajaran inkuiri terbimbing sangat memuaskan dengan perolehan nilai yang cukup tinggi terhadap indikatorindikator pemahaman konsep, jika dibandingkan dengan siswa yang dibelajarkan dengan pembelajaran langsung. Ngetini, Sadia \& Yudana (2014) juga menyatakan bahwa penerapan model pembelajaran inquiri terbimbing yang mendasarkan diri pada paham konstruktivistik sangat sesuai sebagai alternatif pembelajaran sains khususnya dalam pencapaian pemahaman konsep yang tinggi. Kussavita (2014) menyatakan bahwa siswa yang dibelajarkan dengan model pembelajaran inkuiri terbimbing mampu mencapai pemahaman konsep lebih tinggi dibandingkan siswa yang diebelajarkan dengan model pembelajaran konvensional, selain itu model pembelajaran inkuiri tebimbing membuat siswa aktif dalam mengikuti pembelajaran yang berimbas pada pemahaman konsep siswa.

Berdasarkan uraian sebelumnya mengingat pentingnya model pembelajaran inkuiri terbimbing dalam pemahaman konsep maka penelitian ini bertujuan untuk menganalisis efektivitas model pembelajaran inkuiri terbimbing dalam meningkatkan pemahaman konsep IPA siswa SMP.

\section{METODE}

Penelitian ini merupakan penelitian eksperimen semu (quasi exsperiment) dengan rancangan Nonequivalent Pretest Posttest Control Grup Design. Populasi yang digunakan dalam penelitian ini adalah seluruh siswa kelas VIII SMP N 3 Sukasada pada semester genap tahun ajaran 2017/2018 yang berjumlah 106 siswa dan terdistribusi ke dalam empat kelas. Sampel dalam penelitian ini adalah siswa kelas VIIIA dan VIIIB yang dipilih dengan menggunakan teknik cluster random sampling. Siswa kelas VIII A dibelajarkan dengan model pembelajaran inkuiri terbimbing sedangkan kelas VIII B dibelajarkan dengan model pembelajaran langsung.

Penelitian ini menggunakan metode tes untuk memperoleh data pengetahuan awal dan pemahaman konsep siswa. Tes yang digunakan adalah tes pilihan ganda diperluas sebanyak 25 butir soal yang sudah lolos uji asumsi meliputi uji reliabilitas, indeks daya beda (IDB), indeks kesukaran butir tes (IKB) dan konsistensi internal butir.

Data dianalisis menggunakan teknik analisis deskriptif dan inferensial. Analisis deskriptif digunakan untuk mendeskripsikan skor rata-rata pretest dan posttest. Analisis statistik inferensial digunakan untuk menguji hipotesis yang diajukan dalam penelitian ini dengan menggunakan teknik ANCOVA satu jalur 
dengan taraf signifikansi 0,05. Teknik Analisis data dibantu dengan menggunakan SPSS 16.0 for Windows.

Sebelum dilakukan pengujian hipotesis analisis kovarian terlebih dahulu diajukan uji asumsi sebaran data yaitu Uji Normalitas dengan menggunakan statistik Kolmogorov Smirnov dan Shapiro Wilk,Uji Homogenitas dengan menggunakan Levens Test of Equality of Error Variance, Uji Linieritas dengan menggunakan Tes of Linearity dan Kemiringan Garis Regresi (Uji Interaksi) menggunakan Analysis of Variance.

\section{HASIL DAN PEMBAHASAN}

Nilai rata-rata (M) pemahaman konsep pada kelompok eksperimen dan kontrol sebelum diberi perlakuan (pretest) dan sesudah diberi perlakuan (posttest) disajikan pada Gambar 1.

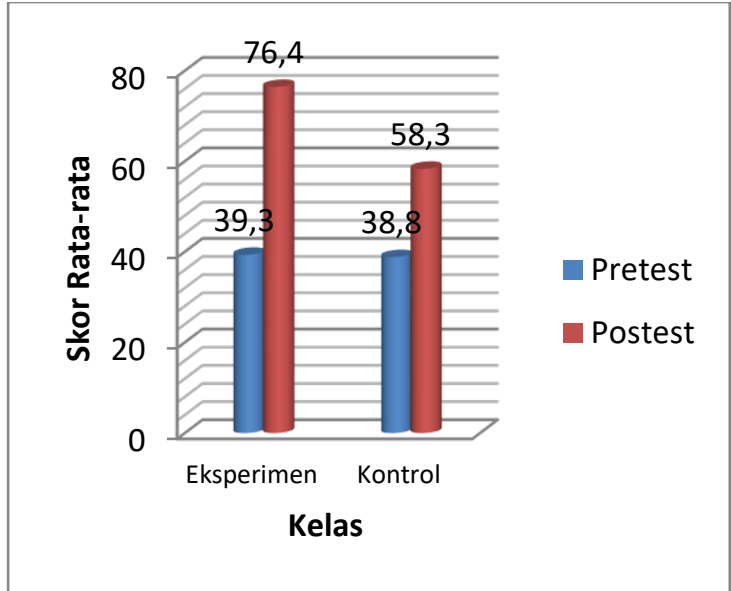

Gambar 1. Skor Rata-Rata Pretest dan Posttest

Berdasarkan data Gambar 1 menunjukkan bahwa hasil pretest siswa pada kelas eksperimen maupun kelas kontrol tidak jauh berbeda. Setelah diberikan perlakuan hasil posttest siswa pada kelas eksperimen maupun kontrol menunjukkan perbedaan perolehan skor yang cukup tinggi, hasil posttest pada kelas eksperimen lebih tinggi dibandingkan dengan hasil posttest pada kelas kontrol. Hal tersebut menunjukkan bahwa pemahaman konsep IPA siswa pada kelas eksperimen lebih tinggi dibandingkan pemahaman konsep IPA siswa pada kelas kontrol. Secara lebih rinci skor rata-rata pemahaman konsep siswa setiap indikator disajikan pada Tabel 2.

Tabel 2. Skor Pemahaman Konsep Pada Setiap Indikator

\begin{tabular}{clcccc}
\hline \multirow{2}{*}{ No } & \multirow{2}{*}{ Indikator } & \multicolumn{4}{c}{ Skor Pemahaman Konsep } \\
\cline { 3 - 6 } & Eskperimen & Kualifikasi & Kontrol & Kualifikasi \\
\hline 1 & Menafsirkan & 79,2 & Cukup & 46,8 & Sangat Kurang \\
2 & Memberi Contoh & 84,6 & Baik & 71 & Cukup \\
3 & Mengklasifikasikan & 81 & Baik & 59,2 & Kurang \\
4 & Merangkum & 71,3 & Cukup & 67 & Cukup \\
5 & Menyimpulkan & 79 & Cukup & 48,5 & Sangat Kurang \\
6 & Membandingkan & 73,5 & Cukup & 50,2 & Sangat Kurang \\
7 & Menjelaskan & 89 & Baik & 68 & Cukup \\
\hline
\end{tabular}

Berdasarkan Tabel 2 pada semua indikator sebaran persentase skor pemahaman konsep IPA. Siswa pada kelas eksperimen memiliki perolehan skor lebih tinggi dibandingkan kelas kontrol. Pada kelas eksperimen indikator menjelaskan memiliki skor paling tinggi diantara ketujuh komponen indikator yang ada dan indikator merangkum memiliki skor terendah diantara ketujuh komonen yang ada. Pada kelas kontrol Indikator memberi contoh merupakan indikator yang dicapai dengan skor tertinggi diantara ketujuh indikator yang ada, sedangkan indikator menafsirkan merupakan indikator yang dicapai dengan nilai terendah. Hal tersebut membuktikan bahwa kelas eksperimen memiliki pencapaian 
pemahaman konsep yang lebih tinggi dari pada kelas kontrol.

Sebelum uji hipotesis, dilakukan beberapa uji asumsi. Hasil uji asumsi menunjukkan bahwa data telah berdistribusi normal, memiliki varian yang homogen, linier antara pretest dengan posttest serta tidak terdapat interaksi antara pengetahuan awal dengan model pembelajaran. Dengan demikian, semua hasil uji asumsi memenuhi syarat untuk dilakukan uji analisis statistik data.

Uji hipotesis dilaksanakan dengan menguji hipotesis nol $\left(\mathrm{H}_{0}\right)$ menggunakan uji ANAKOVA satu jalur. Ringkasan hasil uji ANAKOVA satu jalur tersaji pada Tabel 3.

Tabel 3. Ringkasan hasil uji ANAKOVA

\begin{tabular}{lccccc}
\hline \multicolumn{1}{c}{ Source } & $\begin{array}{c}\text { Type III Sum of } \\
\text { Squares }\end{array}$ & Df & $\begin{array}{c}\text { Mean } \\
\text { Square }\end{array}$ & F & Sig. \\
\hline Corrected Model & $3609.255^{\mathrm{a}}$ & 2 & 1804.628 & 21.238 & 0.000 \\
Intercept & 1490.731 & 1 & 1490.731 & 17.544 & 0.000 \\
PengetahuanAwal & 408.024 & 1 & 408.024 & 4.802 & 0.033 \\
Model Pembelajaran & $\mathbf{3 0 8 6 . 1 9 7}$ & $\mathbf{1}$ & $\mathbf{3 0 8 6 . 1 9 7}$ & $\mathbf{3 6 . 3 2 1}$ & $\mathbf{0 . 0 0 0}$ \\
Error & 4163.514 & 49 & 84.970 & & \\
Total & 235342.000 & 52 & & & \\
\hline
\end{tabular}

Berdasarkan Tabel 3 angka signifikansi pada lajur kelas menunjukkan angka signifikansi lebih kecil dari 0,05. Dengan demikian dapat diambil keputusan bahwa $\mathrm{H}_{0}$ ditolak $\mathrm{H}_{\mathrm{a}}$ diterima. Hal tersebut berarti model pembelajaran inkuiri terbimbing lebih efektif dalam meningkatkan pemahaman konsep siswa dibandingkan model pembelajaran langsung.

\section{Pembahasan}

Pengetahuan awal siswa yang diukur menggunakan pretest merupakan variabel kovariat. Skor rata-rata pretest siswa pada kelas eskperimen dan kelas kontrol secara berturut-turut adalah 39,6 dan 38,8. Skor rata-rata dapat dikendalikan sehingga tidak mempengaruhi pemahaman konsep siswa. Hasil tersebut dipertegas dengan uji interaksi pada pengaruh interaktif antara pengetahuan awal dan model pembelajaran tampak angka signifikansi yang lebih besar dari 0,05 . Hal ini berarti tidak terdapat interaksi antara pengetahuan awal dengan model pembelajaran terhadap pemahaman konsep siswa. Berdasarkan hasil tersebut pemahaman konsep siswa hanya dipengaruhi model pembelajaran setelah dilakukan pengendailan terhadap variabel kovariat. Hal ini sesuai dengan pengertian variabel kovariat yang dinyatakan oleh
Trochim (2006), yaitu variabel kovariat adalah variabel yang digunakan untuk menghilangkan atau mengurangi noise pada analisis data yang disebabkan oleh variabel lain selain variabel yang diteliti sehingga efek dari dari variabel yang diteliti dapat terlihat dengan jelas. Hal tersebut berarti tidak terdapat interaksi antara pengetahuan awal dan model pembelajaran terhadap pemahaman konsep siswa. Hasil rata-rata postest siswa pada kelas eksperimen dan kelas kontrol secara berturut-turut adalah 76,4 dan 58,3. Skor rata-rata pada kelas eksperimen lebih tinggi dibandingkan skor rata-rata pada kelas kontrol.

Model Pembelajaran inkuiri terbimbing menuntut siswa untuk mencari dan menemukan sendiri pengetahuan tentang materi yang diajarkan. Pembelajaran inkuiri terbimbing merupakan pembelajaran yang berlandaskan pandangan konstruktivisme, karena dalam proses pembelajaran siswa harus mengkonstruksi sendiri pengetahuannya. Penerapan pembelajaran inkuiri terbimbing mengajak siswa untuk selalu berpikir dalam memecahkan suatu masalah-masalah nyata yang berkaitan dengan materi yang diajarkan, sehingga informasi yang siswa peroleh dapat tersimpan lebih lama dalam memori otak siswa (Wardani, 2017). 
Pemahaman konsep siswa pada kelas eksperimen lebih tinggi dibandingkan pada kelas kontrol karena dalam proses pembelajaran inkuiri terbimbing terdapat kegiatan merumuskan hipotesis. Pada kegiatan ini siswa diharapkan dapat membuat jawaban sementara dari permasalahan yang ditemukan. Siswa dapat membuat hipotesis berdasarkan pemahaman konsep yang dimiliki siswa melalui proses mencari dan menemukan sendiri informasi melalu berbagai sumber, sehingga siswa dapat menjelaskan dan menafsirkan hipotesis yang dibuatnya berdasarkan konsep maupun teori yang dipahaminya. Pemahaman siswa tersebut mampu melatih proses berpikir siswa. Hal ini sesuai dengan teori belajar kontruktivisme yang dikembangkan oleh Piaget yaitu pengetahuan akan lebih bermakna jika dicari dan ditemukan sendiri oeh siswa (Dahar, 2011). Selain itu Sanjaya (2013) juga menyatakan merumuskan hipotesis akan membuat siswa memperoleh pengalaman yang sangat berharga sebagai upaya mengembangkan mental melalui proses berpikir yang akan membuat siswa mencari, menyelidiki dan menemukan sendiri jawaban dari suatu masalah yang dipertanyakan, akan memberikan kesempatan belajar yang lebih bermakna pada siswa.

Dari hipotesis yang telah dibuat kemudian siswa merancang praktikumnya sendiri. Siswa menentukan alat dan bahan yang digunakan serta langkah kegiatan praktikum yang dilakukan. Kegiatan ini akan melatih pemahaman konsep siswa dalam merancang praktikum, siswa harus menguasai konsep-konsep yang berkaitan dengan materi yang dibahas. Jika siswa memiliki pemahaman konsep yang baik maka konsep yang dipahami tersebut akan dapat menuntun siswa dalam menentukan praktikum yang dilakukan. Apabila siswa tidak menguasai konsep, maka siswa akan mengalami kesulitan dalam membuat prosedur praktikum dan melakukan praktikum. Merancang praktikum dapat melatih proses berpikir kreatif siswa sehingga siswa diharapkan mampu mengaitkan teori (konsep) yang dipahami dengan kehidupan sehari-hari. Kegiatan menyusun prosedur praktikum pada mata pelajaran IPA dapat mengembangkan keterampilan berpikir kritis siswa memecahkan masalah, meningkatkan partisipasi belajar siswa, dan meningkatkan berpikir kreatif siswa yang akan berimbas terhadap tingginya pemahaman konsep siswa (Wiartini, Suardana \& Lasia, 2011). Ketika siswa merancang praktikum akan terjadi interaksi pengetahuan yang telah dimiliki siswa dengan lingkungan tempat belajar. Dengan demikian peningkatan kebermaknaan dan ketertarikan terhadap pembelajaran IPA semakin terbangun dengan sendirinya. Maristania (2017) juga menyatakan pemahaman konsep yang baik akan membuat siswa mampu mencapai kategori-kategori dalam dimensi proses kognitif, seperti mengaplikasikan di mana siswa dapat menggunakan dan menerapkan suatu prosedur dalam keadaan tertentu dan mencipta di mana siswa dapat memadukan bagian-bagian untuk membentuk sesuatu yang baru dan koheren atau untuk membuat susatu produk yang orisinal. Kategori tersebut dapat dicapai ketika siswa mampu merancang percobaan sendiri.

Siswa melakukan praktikum dari rancangan yang telah dibuat. Hasil praktikum kemudian dikumpulkan dan dianalisis. Pada kegiatan ini siswa mengumpulkan dan menganalisis data dari praktikum yang telah dilakukan. Siswa melakukan aktivitas menjaring informasi yang dibutuhkan untuk menguji hipotesis yang telah dibuat melalui serangkaian kegiatan percobaan ilmiah yang telah dilakukan. Kegiatan menganalisis data dapat membuat siswa mampu membandingkan hasil yang ditemukan dengan fakta yang ada, dapat mencontohkan dan mengklasifikasikan hal yang ditemui sesuai dengan permasalahan yang diberikan. Kegiatan ini akan menyebabkan terjadinya interaksi antara pengetahuan yang telah dimiliki sebelumnya dengan pengetahuan atau pengalaman yang baru diperoleh maka akan terjadi interaksi pengetahuan yang telah dimiliki siswa dengan lingkungan tempat belajar. Siswa akan selalu berpikir dalam memecahkan suatu masalahmasalah nyata yang berkaitan dengan materi yang diajarkan, sehingga informasi 
yang siswa peroleh dapat tersimpan lebih lama dalam memori otak siswa (Wardani, 2017). Hal ini membuat pembelajaran yang dialami siswa menjadi lebih bermakna dan akan berdampak pada tingginya pemahaman konsep siswa. Sejalan dengan pendapat Ausubel dalam Dahar (2011) yang menyatakan bahwa belajar bermakna hanya terjadi bila siswa menemukan sendiri pengetahuannya. Belajar penemuan yang bermakna sekali hanyalah terjadi pada penelitian yang bersifat ilmiah. Proses pengumpulan data bukan hanya memerlukan motivasi yang kuat dalam belajar, akan tetapi juga membutuhkan ketekunan dan menggunakan potensi berpikirnya (Sanjaya, 2013). Hal ini sejalan dengan pendapat Bruner (dalam Dahar, 2011) yang menyatakan bahwa belajar penemuan sesuai dengan pencarian pengetahuan secara aktif oleh manusia dengan sendirinya akan memberikan hasil yang paling baik. Berusaha sendiri untuk mencari pemecahan masalah akan menghasilkan pengetahuan yang benarbenar bermakna.

Analisis data yang telah dilakukan kemudian disimpulkan. Saat siswa merangkum seluruh data yang didapat siswa akan menarik kesimpulan untuk menjawab permasalahan yang ditemui berdasarkan fakta-fakta dan konsepkonsep yang didapatkan sehingga siswa mampu menyimpulkan hasil analisisnya sendiri. Proses ini berimbas terhadap tingginya pemahaman konsep siswa. Hal ini sejalan dengan pendapat (Mladjuna, et al, 2015) menyatakan bahwa dalam proses menarik kesimpulan siswa akan melibatkan berbagai aspek dalam kemampuan berpikir yaitu berpikir logis, proses induktif, deduktif, evaluatif, memberikan argumen yang logis dalam pengambilan keputusan. Hal ini sesuai dengan teori konstruktivistik, pengembangan pengetahuan oleh sendiri terjadi melalui suatu proses interaksi antara pengetahuan yang telah dimiliki sebelumnya dengan pengetahuan atau pengalaman yang baru diperolehnya.

Kelas kontrol yang dibelajarkan dengan model pembelajaran langsung, memiliki skor rata-rata lebih rendah dibandingkan kelas eskperimen, hal ini dikarenakan dalam model pembelajaran langsung siswa cenderung hanya mendengarkan guru menjelaskan materi yang diberikan, kemudian guru mengarahkan setiap langkah percobaan yang akan dilakukan sesuai LKS yang diberikan. Guru tidak memberi siswa suatu permasalahan untuk dicari jawabannya atau merumuskan hipotesis dari permasalahan yang diberikan sehingga siswa menjadi pasif dan hanya mendengarkan penjelasan dan arahan dari guru. Hal ini sejalan dengan pendapat Wardani (2015) yang menyatakan bahwa model pembelajaran lagngsung lebih banyak menuntut keaktifan guru daripada pesertadidik, sehingga menyebakan siswa menjadi pasif yang akan berdampak pada rendahnya pemahaman konsep siswa.

Pembelajaran langsung dapat menggali pemahaman konsep siswa ketika guru memberikan kesempatan pada siswa untuk melakukan pelatihan lanjutan. Siswa juga mengembangkan pemahaman konsep yang dimiliki setelah proses demonstrasi materi yang diberikan guru melalui kegiatan praktikum. Siswa menggunakan LKS yang diberikan sebagai penuntun dalam proses kegiatan praktikum sehingga siswa dapat memberi contoh, mengklasifikasikan, membandingkan sesuai dengan pertanyaan yang diberikan. Setelah kegiatan praktikum selesai siswa diharapkan dapat menyimpulkan hasil praktikum yang didapat sama halnya dalam pembelajaran inkuiri. Siswa menyimpulkan dan merangkum kegiatan yang telah dilakukan sehingga siswa akan dapat mengkomunikasikan dan menjelaskan kesimpulan yang dibuatnya berdasarkan materi yang telah dipahami setelah guru mendemonstrasikan konsep yang diajarkan.

Pembelajaran dengan model pembelajaran langsung membuat siswa tidak dapat mengembangkan sendiri kemampuannya dan menjadi cenderung bergantung kepada informasi yang diberikan oleh guru. Hal tersebut dapat dilihat selama kegiatan pembelajaran berlangsung, siswa hanya mendengarkan materi yang dijelaskan oleh guru lalu melakukan percobaan sesuai instruksi yang diberikan guru. Akibatnya siswa merasa bosan dan kurang aktif dalam 
pembelajaran sehingga akan berpengaruh kepada rendahnya pemahaman konsep siswa. Sejalan dengan pendapat Kurniawati (2014) yang menyatakan bahwa pembelajaran dengan model pembelajaran langsung yang sering diterapkan guru mengakibatkan siswa enggan dan jenuh dalam menerima materi pelajaran sehingga tujuan yang ditetapkan tidak tercapai secara optimal dan menyebabakan rendahnya pemahaman konsep siswa.

Hasil pemahaman konsep setiap indikator menunjukkan bahwa pada kelas eksperimen, indikator menjelaskan memperoleh skor paling tinggi dan indikator merangkum memperoleh skor paling rendah. Hal tersebut terjadi karena dalam kegiatan pembelajaran inkuiri seperti merumuskan hipotesis, merancang percobaan, dan menyimpulkan membuat siswa terbiasa menyampaikan argumentasi dengan menggunakan konsep yang dipahaminya. Hal tersebut menyebabkan siswa terbiasa menjelaskan permasalahan yang ada sehingga mampu mencapai skor tertinggi pada indikator menjelaskan. Indikator merangkum merupakan indikator terendah yang dicapai siswa pada kelas eksperimen. Hal tersebut dikarenakan proses merangkum hanya dilakukan pada kegiatan menyimpulkan sehingga siswa hanya melatih kegiatan merangkum pada akhir pembelajaran saja sehingga kondisi siswa cenderung kurang fokus untuk mengikuti pembelajaran hal tersebut yang menyebabkan siswa sedikit kurang dalam aspek merangkum. Meskipun indikator merangkum merupakan indikator terendah yang dicapai siswa namun skor yang ditunjukkan masih berada pada kategori sedang sehingga hal tersebut menurut peneliti bukanlah sesuatu hal yang buruk dalam pemahaman konsep siswa.

Pada kelas kontrol indikator tertinggi terdapat pada indikator memberi contoh dan indikator terendah terdapat pada indikator menafsirkan. Hal tersebut terjadi dikarenakan dalam proses pembelajaran langsung setelah kegiatan mendemontrasikan pengetahuan dan keterampilan yang dilakukan oleh guru siswa akan dilatih untuk memberikan contoh kembali berdasarkan konsep yang telah dijelaskan oleh guru. Kegiatan memberi contoh terjadi pada sintak mengecek pemahaman dan memberikan umpan balik hal ini menyebabkan siswa terlatih memberikan contoh dalam proses pembelajaran. Indikator terendah pada kelas kontrol dicapai pada indikator menafsirkan. Hal tersebut terjadi karena dalam proses pembelajaran langsung aktivitas siswa cenderung kurang aktif, terutama dalam kegiatan bertanya dan menjawab pertanyaan guru. Siswa dalam kegiatan pembelajaran langsung cenderung hanya mendengarkan dan memperhatikan apa yang dijelaskan oleh guru sehingga siswa kurang terlatih untuk memberikan argumentasi dalam kegiatan pembelajaran sehingga menyebabkan siswa kurang mengembangkan pemahaman konsep yang dimilikinya sehingga siswa kurang dalam menafsirkan yang berimbas terhadap rendahnya pemahaman konsep siswa.

Hasil penelitian ini konsisten dengan beberapa penelitian yang telah dilakukan oleh peneliti sebelumnya yaitu penelitian yang dilakuakan oleh Maxwell (2015) dan Almuntasheri et al (2016) dalam penelitiannya tentang pengaruh model pembelajaran inkuiri terbimbing dalam pelajaran IPA sama-sama menyatakan siswa yang belajar menggunakan model pembeljaran inkuiri terbimbing menunjukkan keterlibatan yang lebih tinggi dibandingkan dengan siswa yang menerima instruksi tradisional dan inkuiri terbimbing menunjukkan perbaikan yang signifikan terhadap pemehamana konsep pembelajaran. Selain itu Setyawati, Candiasa \& Yudana (2015) menyatakan bahwa Model pembelajaran inkuiri terbimbing mampu memberikan kualifikasi yang lebih baik dibandingkan model pembelajaran konvensional Selain itu Tariani, Syahrudin \& Parmiti (2014) menyatakan bahwa siswa yang dibelajarkan dengan model pembelajaran inkuiri terbimbing mampu mencapai pemahaman konsep lebih tinggi dibandingkan siswa yang diebelajarkan dengan model pembelajaran konvensional, selain itu model pembelajaran inkuiri tebimbing membuat siswa aktif dalam mengikuti pembelajaran yang berimbas pada tingginya pemahaman konsep siswa. 
Meskipun model pembelajaran inkuiri terbimbing lebih unggul diterapkan dalam meningkatkan pemahaman konep siswa, namun belum secara optimal dapat mencapai pemahaman konsep pada kategori baik ataupun sangat baik. Hanya Indikator memberi contoh, mengklasifikasikan dan menjelaskan yang mampu mencapai kategori baik sedangkan indikator menafsirkan, meringkas, menyimpulkan, dan membandingkan hanya mampu mencapai kategori cukup . Hal ini disebabkan oleh adanya beberapa hal yang menjadi kendala dalam proses pembelajaran.

Pertama, pada awal pertemuan beberapa siswa masih terbawa dengan kebiasan sebelumnya yaitu terbiasa hanya mendengarkan, mecatat dan kurang terlalu aktif dalam proses pembelajaran siswa masih kurang untuk bereksplorasi secara mandiri dan belum mempunyai kepercayaan diri untuk memecahkan suatu permasalahan. Kebanyakan siswa masih menunggu instruksi dan penjelasan guru tanpa ada usaha untuk menemukan dan mengkonstruksi sendiri penyelesaian dari pemasalahan yang diberikan, hal ini menyebabkan siswa kurang memilki kemandirian dalam menyelesaikan permasalahan yang diberikan, sehingga harus lebih memberikan pertanyaanpertanyaan penuntun kepada siswa agar siswa menjadi aktif dalam bereksplorasi sehingga akan menyebabkan seluruh indikator yang diharapan dapat tercapai dengan sangat baik misalnya dalam kegiatan praktikum pada saat menganalisis data sebaiknya lebih menekankan pertanyaan-pertanyaan pendukung yang berhubungan dengan indikator pemahaman konsep sehingga indikator yang masih berada pada kualifikasi cukup dapat ditingkatkan agar siswa terbiasa dengan pertanyaan-pertanyaan yang berhubungan dengan pemahaman konsep siswa.

Kedua pada pertemuan awal saat menerapkan model pembelajaran inkuiri siswa belum terbiasa dengan LKS berorientasi inkuiri terbimbing yang diberikan, LKS yang biasa mereka gunakan telah menyajikan langkahlangkah kerja yang jelas dan terstruktur, LKS berorientasi inkuiri yang digunakan menuntut mereka untuk merumuskan hipotesis kemudian melaksanakan kegiatan praktikum dengan desain dan kontrol eksperimen sendiri yang dipandu dengan pertanyan pembimbing. Siswa mengalami kesulitan dalam menentukan prosedur kerja yang akan digulakukan guna menggali konsep-konsep yang terkandung dalam permasalahan yang dhdapi, sehinga peran guru dalama memberikan pijakan dan bimbingan sangat diperlukan pada awal-awal pertemuan agar siswa dapat memahami maksud dari LKS yang diberikan.

Ketiga alat dan bahan yang terdapat pada sekolah sangat terbatas sehingga menyebabkan siswa harus bergilir menggunakan alat. Hal tersebut menyebabkan kegiatan pembelajaran memerlukan banyak waktu, sehingga ada baiknya guru harus mengatur strategi tersendiri agar siswa dapat melakukan praktikum dan tidak memerlukan banyak waktu. salah satunya dengan merancang praktikum sederhana dimana alat dan bahannya dapat dibawa oleh siswa itu sendiri.

\section{SIMPULAN DAN SARAN}

Berdasarkan hasil penelitian dan pembahasan dapat disimpulkan bahwa terdapat perbedaan pemahaman konsep IPA antara siswa yang dibelajarkan dengan model pembelajaran inkuiri terbimbing dan model pembelajaran langsung. Kelompok siswa yang belajar dengan model pembelajaran inkuiri terbimbing menunjukkan pemahaman konsep lebih tinggi dibandingkan dengan kelompok siswa yang belajar dengan model pembelajaran langsung.

Adapun saran yang dapat disampaikan terkait dengan penelitian ini adalah sebagai berikut.

Bagi guru bidang studi IPA, model pembelajaran inkuiri terbimbing dapat digunakan sebagai alternatif pembelajaran untuk meningkatkan pemahaman konsep siswa dalam pembelajaran IPA. Guru harus lebih memperhatikan indikator pemahaman konsep agar seluruh indikator dapat dicapai dengan baik. Guru diharapkan memberikan LKS dan pertanyaan-pertanyaan penuntun yang mudah dimengerti siswa agar kegiatan 
yang diinginkan tercapai. Guru juga harus dapat memanagemen waktu agar dalam proses pembelajaran tidak mengalami kekurangan waktu sehingga menyebabkan beberapa materi tidak tersampaikan dengan baik.

Bagi sekolah, diharapkan melengkapi sarana dan prasana terutama alat-alat praktikum IPA untuk menunjang proses pembelajaran agar menjadi lebih baik.

Bagi peneliti selanjutnya diharapkan melakukan penelitian lebih lanjut tentang upaya meningkatkan pemahaman konsep IPA siswa dengan menggunakan materi yang berbeda, jumlah sampel yang berbeda dan tempat pengambilan data yang berbeda, agar penelitian dengan menggunakan model pembelajaran inkuiri terbimbing dapat memberikan informasi yang jauh lebih luas.

\section{DAFTAR RUJUKAN}

Anderson, Lorin W \& David R. Krathwohl.2015. Kerangka Landasan untuk Pembelajaran Pengajaran dan Asesmen. Yogyakarta: Pustaka Pelajar.

Almuntasheri,s.dkk.2016. The Effectiveness of a Guided Inquirybased, Teachers' Professional Development Programme on Saudi Students' Understanding of Density. Vol 27. No 1 Science Education International

Terdapat pada https://files.eric.ed.gov/fulltext/EJ11 00181.pdf (diakses pada 12 februari 2018)

Dahar.R.W.2012.Teori-Teori Belajar. Jakarta: Erlangga

Djamarah, Syaiful Bahri \& Aswan

Zain.2013.

Strategi Belajar Mengajar. Jakarta: Rineka Cipta. Tersedia online pada http://library.um.ac.id/freecontents/index.php/buku/detail/strat egi-belajar-mengajar-edisi-revisisyaiful-bahri-djamarah-dan-aswanzain-37728.html (diakses pada tanggal 10 Maret 2018)

Hariyadi, Ibrohim \& Rahayu. 2016. Pengaruh Model Pembelajaran Inkuiri Terbimbing Berbasis Lingkungan Terhadap Keterampilan Proses dan Penguasaan Konsep
IPA Siswa Kelas VII Pada Materi Ekosistem. Volume 1 Nomor 8. Universitas Negeri Malang. Teori Penelitian dan Pengembangan terdapatpada https://media.neliti.com/media/publi cations/210834-pengaruh-modelpembelajaran-inkuiriterb.pdf (diakses pada tanggal 25 Mei 2018)

Kussavita, R. 2007. Aplikasi Pakem (Pembelajaran Aktif Kreatif Efektif Menyenangkan) Model Rancangan Alat untuk Meningkatkan Prestasi Belajar Biologi Siswa Kelas VII SMA Negeri 1 Ambarawa. Skripsi. Surakata: Universitas Sebelas Maret

Kemendikbud. 2017. Laporan Hasil Ujian Nasional 2017/2018. Diperoleh dari http://litbang.kemdikbud.go.id

Kurniawati. 2014. Pengaruh Pembelajaran Inkuiri Terbimbing Peer Instuction Terhadap Penguasaan Konsep dan Berpikir Kritis Siswa. Vol 1 no 10. Jural Pendidikan Fisika Indonesia. Terdapat pada https://media.neliti.com/media/publi cations/120003-ID-pengaruhpembelajaran-inkuiri-terbimbing.pdf (diakses pada tanggal 11 Januari 2018)

Kunandar. 2010. Guru Profesional Implementasi Kurikulum Tingkat Satuan Pendidikan (KTSP) dan Sukses dalam Sertifikasi Guru. Jakarta: Rajawali Pers.

Mladjuna, Saehana \& Syamsu. 2015 Pengaruh Model Pembelajaran Inkuiri Terbimbing Terhadap Pemahaman Konsep Siswa pada Mata Pelajaran Fisika di SMP Negeri 19 Palu. Vol 5 No 1. Jurnal Pendidikan Fisika Tadulako (JPFT). Terdapat http://jurnal.untad.ac.id /jurnal/index.php/EPFT/article/view/ 7126/5730 (diakses pada tanggal 5 mei 2018)

Maxwell.2015. Effects of using inquirybased learning on science achievement for fifth-grade students.USA. Vol 16 no 1. Royston Elementary School terdapat pada https://eric.ed.gov/?id=EJ1070728 (diakses pada 12 januari 2018) 
Murfiah, U.(2017). Pembelajaran Terpadu Teori dan Praktik Terbaik di Sekolah. Bandung;PT Refika aditama

Martin, O, M, Ina V S Mulis., Pierre F \& Martin, H. 2015. International Result in Science. Tersedia pada http://timss2015.org/wp-

content/uploads/filebase/full\%20pdfs/ T15-International-Results-in-

Mathematics-Grade-4.pdf (diakses pad tanggal 29 Juni 2018)

Maristania. 2017. Analisis Pelaksanaan Praktikum dan Permasalahannya Pada Materi Organisasi kehidupan. Skripsi. Universitas Lampung

Ngertini, Sadia, Yudana. 2013.Pengaruh implementasi Model Pembelajaran Inkuiri Terbimbing Terhadap Kemampuan Pemahaman Konsep dan Literasi Sains Siswa Kelas $X$ Sma PGRI 1 Amplapura. volume 4 no 1. Ejorunal Program Pascasarjana Universitas Pendidikan Ganesha terdapat pada http://pasca.undiskha.ac.id/e-

journal/index.php/journal_ap/article/vi ew/1012 diakses pada tanggal (4 November 2017)

Permendikbud .(2013). Peraturan menteri pendidikan dan Kebudayaan Nomor 21 tahun 2016 Tentang Standar isi.

Sanjaya, W. 2013 Strategi Pembelajaran Berorientasi Standar Proses Pendidikan. Jakarta: Kencana Paranamedia Group

Setyawati, Candiasa \& Yudana. 2015. Pengaruh Model Pembelajaran Inkuiri Terbimbing Terhadap Pemahaman Konsep dan Keterampilan Proses Sains Siswa Kelas IX IPA SMA Negeri 2 Kabupaten Badung. Jurnal Pendidikan dan Pengajaran Universitas Pendidikan Ganesha. Terdapat pada https://media. neliti.co/media/ publications /79795ID-pengaruh -model-pembelajaraninkuiri-terb.pdf (diakses pada tanggal 3 Desember 2017)

Tariai, Syahrudin, Parmiti. 2014. Pengaruh Model Pembelajaran Inkuiri Terbimbing Terhadap Pemahaman Konsep IPA Siswa Kelas V. Volume 2 no 1. Universitas Pendidikan Ganesha terdapat pada http://download.portal.garuda.org/arti cle.php?article $=304043 \& v a l=1342 \&$ tit le=PENGARUH\%20MODEL\%20PE MBELAJARAN\%20INKUIRI\%TERBI MBING\%TERHADAP\%PEMAHAMA N\%KONSEP\%20IPASISWA\%20KEL AS\%20V (diakses pada tanggal 4 November 2017)

Trianto. 2010. Mendesain Model Pembelajaran Inovatif-Progresif dan Kontekstual. Jakarta: PT Kencana

Trochim, W. M. 2006. Convergent and Discriminant Validity Research Methods Knowledge Base. Tersedia padahttp://www.social researchmet ho ds.net/kb/convdisc.php ( diakses pada tanggal 10 Juni 2018).

Widiwati, P. 2015. Analisis Pemahaman Konsep Dalam Pelajaran IPA Pada Siswa Kelas IV SD Di Gugus II Kecamatan Banjar. Univerista Pendidikan Ganesha volume 3 no 1 terdapat pada https://ejorunal.undiksha.ac.id/index. php/JJPGSD/article/view/5847 (diakses pada tanggal 1 November 2017)

Wardani.2015. Pengaruh Model Pembelajaran Inkuiri Terbimbing Berbasis Lingkungan Terhadap Keterampilan Proses dan Penguasaan Konsep IPA Siswa Kelas VII SMP Negeri 3 Kopang Pada Materi Ekosistem. Volume 3 no 4. Pendidikan Dasar PascasarjanaUniversitas Negeri Malang terdapat pada

http:/jorunal.um.ac.id/index.php/jptpp/ article/view/8891/4285 (diakses pada tanggal 4 November 2017)

Wiartini, Suardana \& Lasia. 2011. Pemanfaatan Lingkungan Lokal Dalam Membuat Prosedur Praktikum Penelitian. No 1-3. Jurnal Pendidikan dan Pengajaran. Universitas Pendidikan Ganesha terdapat pada https://ejorunal.undiksha.ac.id/index. php/JJarticle/view/5847 (diakses pada tanggal 3 July 2018. 